Slamet Mardiyanto Rahayu. (2019). Avifauna di Desa Makmur Jaya, Kecamatan Tikke Raya, Kabupaten Pasangkayu, Provinsi Sulawesi Barat. Journal Bioeksperimen. Vol. 5 (2) Pp. 87-98. Doi: 10.23917/bioeksperimen.v5i2.2795

\title{
AVIFAUNA DI DESA MAKMUR JAYA, KECAMATAN TIKKE RAYA, KABUPATEN PASANGKAYU, PROVINSI SULAWESI BARAT
}

\author{
Slamet Mardiyanto Rahayu \\ Universitas Islam Al-Azhar, Jl. Unizar No. 20, Turida, Sandubaya, Mataram \\ E-mail: slamet.mardiyantorahayu84@gmail.com \\ Paper diterima : 24 November 2018, Paper publish : September 2019
}

\begin{abstract}
Biodiversity is a component that is sensitive to changes in land use. Birds are an avifauna found in almost every place and have an important position as one of Indonesia's animal wealth. The high level of biodiversity is not supported by data and information about its distribution, the taxonomy is still limited and not well documented. Based on this, it is necessary to explore the distribution of birds in various regions, so that they can be collected in a database to support the bioconservation program. Therefore, this research needs to be done to determine the type of avifauna in Makmur Jaya Village, Tikke Raya District, Pasangkayu Regency, West Sulawesi Province. The research was in the form of exploration by observing and recording the species of birds found. Based on the research found 23 types of avifauna in Makmur Jaya Village, Tikke Raya District, Pasangkayu Regency, West Sulawesi Province, namely: Alcedo atthis, Aythya australis, Rhyticeros cassidix, Chalcophaps stephani, Streptopelia chinensis, Macropygia amboinensis albicapilla, Corvus enca, Turacoena manadensis, Phaenicophaeus calyorhynchus, Dicrurus hottentottus, Todiramphus chloris, Hirundo tahitica, Aethopyga siparaja, Nectarinia jugularis, Passer montanus, Gallus gallus, Loriculus stigmatus, Pycnonotus aurigaster, Gallirallus torquatus, Ninox punctulata, Phylloscopus sarasinorum, and Bubulbus ibis.
\end{abstract}

Keywords: Avifauna, Makmur Jaya, Pasangkayu, Tikke Raya

\section{Pendahuluan}

Tekanan terhadap kehidupan berbagai spesies dan kerusakan habitat alami akan terus berlanjut. Langkah studi ilmiah yang harus dilakukan adalah mengupayakan pengawetan, pemanfaatan, dan pelestarian keanekaragaman hayati dengan cara mengidentifikasi daerahdaerah kaya akan keanekaragaman hayati (Atmoko, 2001).

Penggunaan lahan dapat berupa pemukiman dan pembangunan dalam skala kecil maupun besar (Missana et al., 2003). Alih fungsi lahan telah mengubah, mendegradasi, dan merusak bentang alam dalam skala luas. Kerusakan habitat mendorong spesies dan bahkan seluruh komunitas menuju ambang kepunahan. Ancaman utama pada keanekaragaman hayati akibat kegiatan manusia adalah kerusakan habitat, fragmentasi habitat, degradasi habitat (termasuk polusi), perubahan iklim global, pemanfaatan spesies yang berlebihan untuk kepentingan manusia, invansi spesies-spesies asing dan meningkatnya penyebaran penyakit serta sinergi dari faktorfaktor tersebut. Spesies dan komunitas yang terancam punah menghadapi sedikitnya dua atau lebih dari masalah tersebut sehingga mendorong kepunahan dan menyulitkan usaha perlindungan (Indrawan dkk., 2007).

Aktivitas perubahan fungsi lahan tersebut secara signifikan mengubah biodiversitas, kondisi tanah, aliran air dan sedimen (Missana et al., 2003). Biodiversitas merupakan komponen yang sensitif terhadap perubahan fungsi lahan (Zebisch etal., 2003). Pernyataan ini ditunjukkan dengan adanya kepunahan spesies yang luar biasa akibat aktivitas manusia (Chemini et al., 
2003). Penurunan spesies burung tidak hanya berpengaruh pada populasinya tetapi juga akan mempengaruhi semua komposisi komponen di dunia (Ramirez, 2010). Perubahan penggunaan lahan yang terjadi saat ini merupakan faktor penting yang mempengaruhi biodiversitas pada masa yang akan datang di daerah tropis (James et al., 2017). Jutaan hektar hutan tropis telah terfragmentasi setiap tahun dan menyebabkan berkurangnya keanekaragaman burung (Sodhi et al., 2011).

Burung adalah avifauna yang dijumpai hampir di setiap tempat dan mempunyai posisi penting sebagai salah satu kekayaan satwa Indonesia. Studi ekologis menyebutkan bahwa burung mempunyai hubungan yang baik dengan lingkungan, sehingga dapat dijadikan indikator kesehatan lingkungan dan keanekaragaman hayati (Rusmendro dkk., 2009). Peran fungsional burung dalam ekosistem adalah penyebaran biji, penyerbukan, pengendalian hama dan dekomposisi (Sekercioglu et al., 2004). Faktor yang mempengaruhi keberadaan burung di lingkungan antara lain ukuran dan struktur vegetasi, kompetisi dengan spesies, predator, serta residu pestisida (Chace and Walsh, 2004). Vegetasi merupakan elemen struktur dasar dalam habitat terestrial (Lughadha et al., 2005). Peranan vegetasi dalam ekosistem diantaranya sebagai penyedia makanan, mengontrol erosi dan digunakan untuk tempat tinggal spesies (Balvanera et al., 2006). Indonesia termasuk lima negara dengan biodiversitas tinggi yaitu menempati urutan kelima dengan perolehan \pm 1539 jenis burung (Atmoko, 2001).

Desa Makmur Jaya berada di Pulau Sulawesi, yang secara administratif termasuk dalam Kecamatan Tikke Raya, Kabupaten Pasangkayu, Provinsi Sulawesi Barat. Arini dkk. (2011) menyebutkan bahwa sebagai salah satu wilayah di Kawasan Timur Indonesia maka Pulau Sulawesi menyimpan berjuta misteri berkaitan dengan potensi sumber daya alamnya. Alam Sulawesi menjadi perhatian konservasionis dunia karena menjadi tempat hidup berbagai satwa endemik yang bernilai global. Dalam bidang ornitologi, Sulawesi merupakan surga bagi kehidupan burung yang tiada bandingannya, bahkan ornitologiwan dari segala penjuru dunia memberikan prioritas utama untuk pulau ini. Tallei et al. (2018) menyebutkan bahwa masalah penurunan populasi burung di Sulawesi dikarenakan kerusakan habitat dan perburuan. Saat ini, keberadaan burung di suatu pulau semakin terpojok oleh tingginya eksploitasi terhadap pulau tersebut yang dilakukan oleh manusia dan adanya spesies invasif (Tobias et al., 2013).

Tingginya tingkat biodiversitas ini tidak ditunjang dengan data-data dan informasi mengenai penyebarannya, taksonominya masih terbatas dan tidak terdokumentasi dengan baik. Respon masyarakat biologi terhadap perubahan global melaui konservasi tidak dapat dielakkan (Ladin et al., 2016). Konservasi burung merupakan sebuah misi global di daerah tropis (Şekercioğlu, 2012). Berdasarkan hal tersebut, maka perlu diadakan eksplorasi persebaran burung di berbagai daerah, sehingga dapat terkumpul dalam database guna mendukung program biokonservasi. Oleh karena itu, perlu dilakukan penelitian ini untuk mengetahui jenis avifauna di Desa Makmur Jaya, Kecamatan Tikke Raya, Kabupaten Pasangkayu, Provinsi Sulawesi Barat.

\section{Metode Penelitian}

\section{Waktu dan Tempat}

Penelitian dilakukan pada bulan Juli 2017 di Desa Makmur Jaya, Kecamatan Tikke Raya, Kabupaten Pasangkayu, Provinsi Sulawesi Barat ( ${ }^{\circ} 21^{\prime} 17^{\prime \prime}$ LS dan $119^{\circ} 25^{\prime} 27^{\prime \prime}$ BT).

\section{Alat dan Bahan}

Alat dan bahan yang digunakan dalam penelitian ini adalah teropong binokuler, kamera, buku catatan pengamatan, dan buku identifikasi burung, dan alat tulis.

\section{Cara Kerja}

Penelitian berupa eksplorasi dengan metode jelajah di Desa Makmur Jaya, Kecamatan Tikke Raya, Kabupaten Pasangkayu, Provinsi Sulawesi Barat, yaitu melakukan pengamatan avifauna menggunakan teropong binokuler. Avifauna 
yang dijumpai kemudian diidentifikasi dengan mengacu pada Buku Keanekaragaman Avifauna Beberapa Kawasan Konservasi Propinsi Sulawesi
Utara dan Gorontalo yang disusun oleh Arini dkk. (2011).
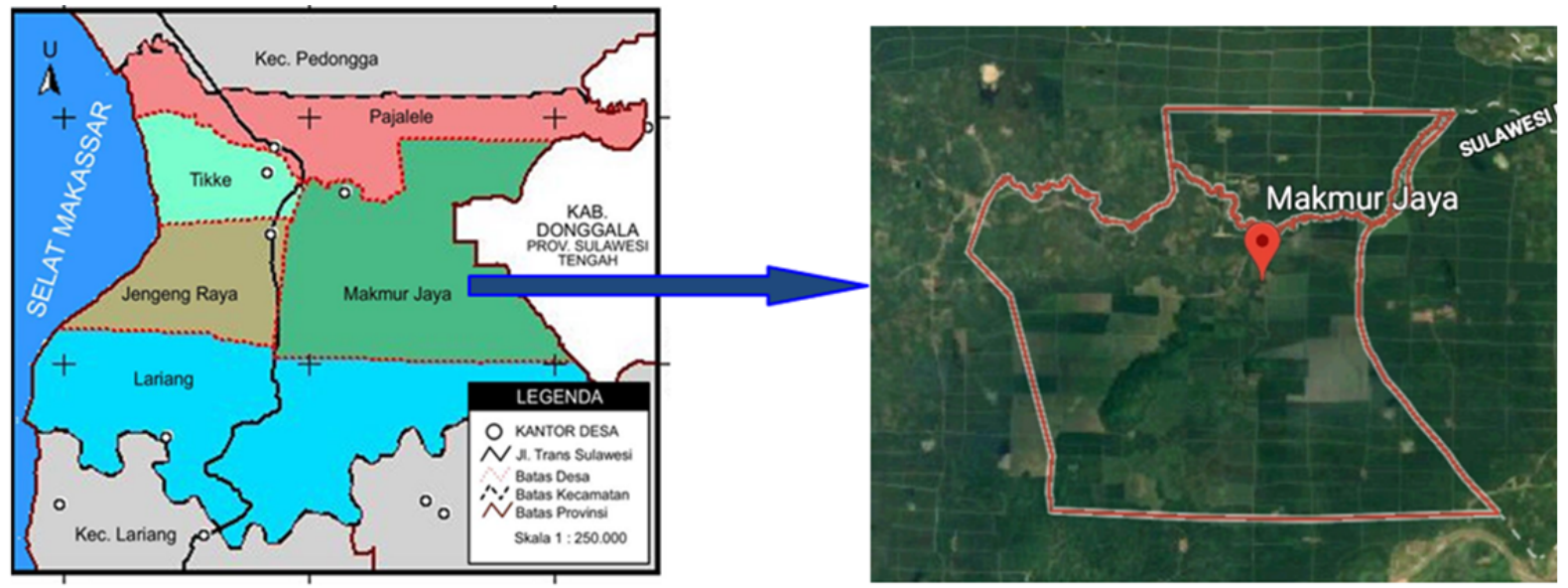

Gambar 1. Lokasi Penelitian Avifauna di Desa Makmur Jaya, Kecamatan Tikke Raya, Kabupaten Pasangkayu,

Provinsi Sulawesi Barat

\section{Hasil Dan Pembahasan}

Berdasarkan penelitian diperoleh 23 jenis avifauna di Desa Makmur Jaya, Kecamatan Tikke Raya, Kabupaten Pasangkayu, Provinsi Sulawesi Barat.

\section{Alcedo atthis}

Nama Lokal: Raja Udang Erasia

Nama Internasional: Common Kingfisher

Kriteria Kepunahan: Beresiko Rendah

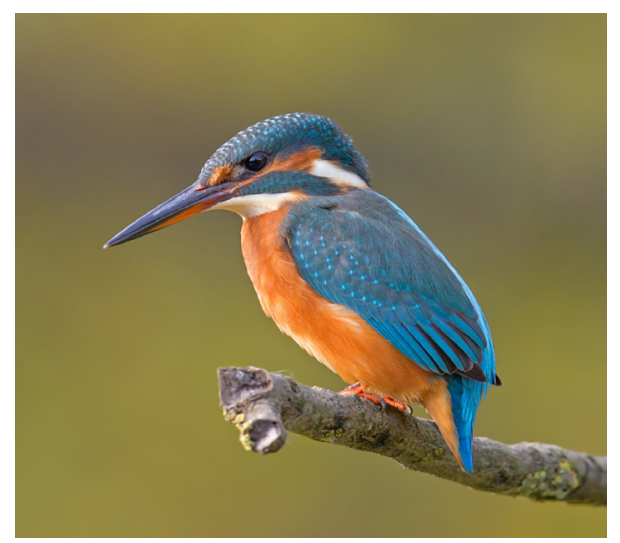

Gambar 2. Alcedo attbis

Deskripsi:

Berukuran 14.5-18.5 cm. Garis tengah biru terang cemerlang. Pada punggung dan tunggir, tanda pada leher keputih-putihan. Bagian bawah merah karat kayu manis.
Sering mengunjungi sungai-sungai dan anak-anak sungai, danau, kolam dan rawarawa di antara kawasan yang dihutankan dan daerah yang lebih terbuka juga mangrove, muara sungai dan tepi pesisir yang tersembunyi. Jenis ini menyukai terbang rendah dan sangat cepat. Sarang berada di dalam lubang di tepi-tepi sungai, jumlah telur berkisar antara 2-10 butir.

\section{Aythya australis}

Nama Lokal: Itik Mata Putih

Nama Internasional: Australian Pochard

Kriteria Kepunahan: Beresiko Rendah

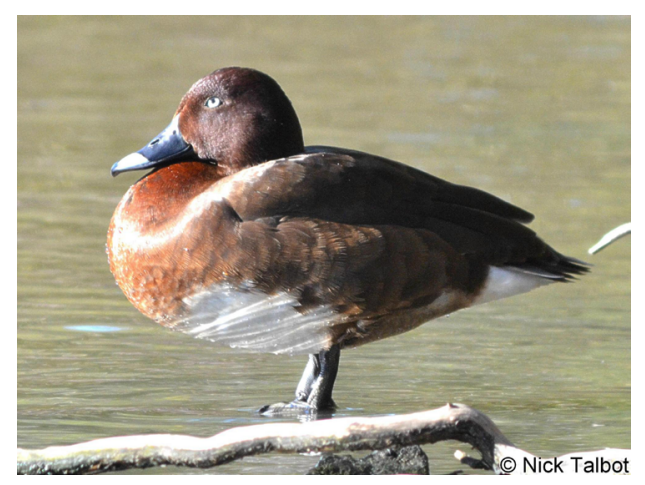

Gambar 3. Aythya australis

Deskripsi:

Berukuran 45-60 cm. Coklat tua, penutup 
sayap bawah putih, perut pucat. Ketika sedang terbang, pita putih melebar menutup sepanjang sayap atas. Sayap bawah putih, tepinya gelap sempit. Jenis bebek yang pandai menyelam, dengan cara menundukkan kepala ke dalam air kemudian bebek ini akan menyelam dengan dorongan kaki berselaput kuat. Jenis ini mampu menyelam dan bertahan di bawah air hingga satu menit. Menyukai habitat rawa, danau, dan sungai besar dan menghindari perairan pantai. Itik ini jarang terlihat di daratan dan tidak pernah di atas pohon. Perbedaan antara jantan dan betina terletak pada matanya. Itik jantan memiliki mata berwarna putih sedangkan betina berawarna coklat.

\section{Rhyticeros cassidix}

Nama Lokal: Julang Sulawesi, Burung Taon Nama Internasional: Konnobed Hornbill Kriteria Kepunahan: Beresiko Rendah

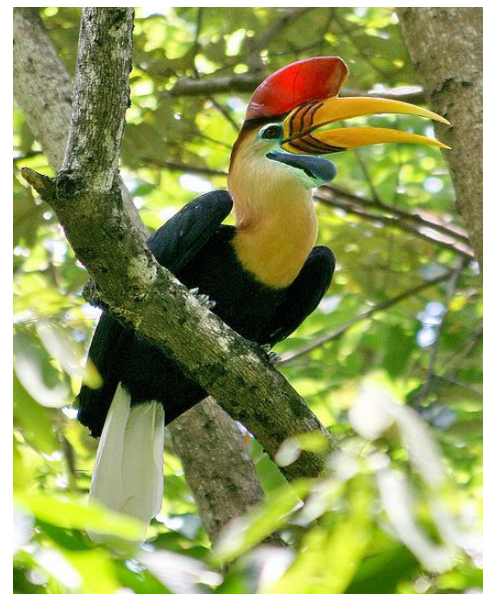

Gambar 4. Rhyticeros cassidix

\section{Deskripsi:}

Memiliki ukuran lebih besar dibandingkan kangkareng, sekitar $104 \mathrm{~cm}$. Tubuh dan sayapnya hitam dan ekor putih. Memiliki sebuah tanduk (casque) yang sangat besar di atas paruh, merah pada jantan dan kuning pada betina. Paruhnya sendiri kuning pada kedua jenis kelamin. Memiliki sebuah kantung biru pada tenggorokan. Jenis ini sangat mudah dilihat karena ukuran tubuhnya yang besar.
Memanfaatkan pohon-pohon besar untuk dijadikan sarang. Sarang yang dibuat sangat unik, dari lubang besar ditutup dengan menggunakan lumpur menjadi lubang kecil. Burung betina bertugas mengerami telurnya dan memberikan makan pada anak-anaknya di dalam sarang. Sementara jantan mencari makan dan memberikan kepada betinanya. Buah beringin adalah makanan kesukaannya. Martin dan Blackburn (2010) melaporkan bahwa kemelimpahan R.cassidix berkurang dengan pesat karena tingginya gangguan pada Hutan Lambusango di Sulawesi.

\section{Chalcophaps stephani}

Nama Lokal: Delimukan Timur

Nama Internasional: Stephans Dove

Kriteria Kepunahan: Beresiko Rendah

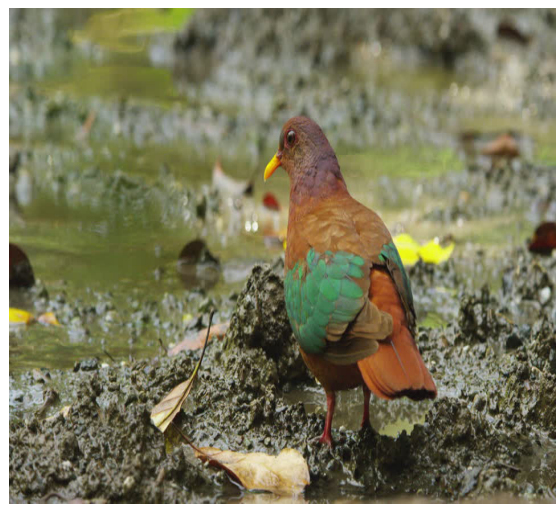

Gambar 5. Chalcophaps stephani

Deskripsi:

Berukuran $25 \mathrm{~cm}$. Kedua sayap dan punggung hijau berkilap. Bahu bertanda putih. Dua palang abu-abu terang pada punggung bawah. Jenis ini sering terlihat mencari makan di tanah dan sewaktu lepas landas dengan terbang cepat menghindari pangamat dan sayap yang hijau dan dua garis pucat di punggung bawah terlihat sangat jelas. Kedua garis tersebut berwarna bungalan.

\section{Streptopelia chinensis}

Nama Lokal: Tekukur Biasa

Nama Internasional: Spotted Dove

Kriteria Kepunahan: Beresiko Rendah 


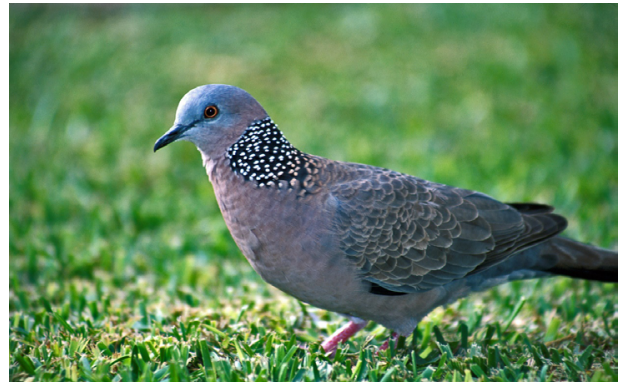

Gambar 6. Streptopelia chinensis

Deskripsi:

Tubuh berukuran sedang $(30 \mathrm{~cm})$. Warna coklat kemerahjambuan. Ekor tampak panjang. Bulu ekor terluar dengan tepi putih tebal. Bulu sayap lebih gelap dibanding tubuh. Ada bercak-bercak putih khas pada leher. Iris jingga, paruh hitam dan khaki merah. Sarang sangat sederhana, datar, berupa ranting tersusun pada semaksemak rendah. Telur berwarna putih polos yang biasanya berjumlah dua buah.

\section{Macropygia amboinensis albicapilla}

Nama Lokal: Uncal Ambon

Nama Internasional: Slender-billed Cuckoo-dove

Kriteria Kepunahan: Beresiko Rendah

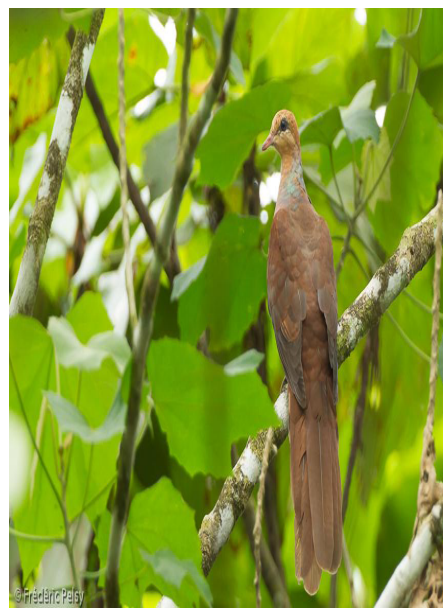

Gambar 7. Macropygia amboinensis albicapilla

Deskripsi:

Memiliki ukuran 35.5-37 cm. Berwarna coklat kemerahan. Bagian atas lebih gelap, bagian bawah lebih pucat dan dada berpalang hitam. Cukup umum dijumpai pada rawa-rawa, lahan budidaya yang pohonnya jarang dan kadang semak dengan pepohonan yang jarang.

\section{Corvus enca}

Nama Lokal: Gagak Hutan

Nama Internasional: Slender Billed Crow

Kriteria Kepunahan: Beresiko Rendah

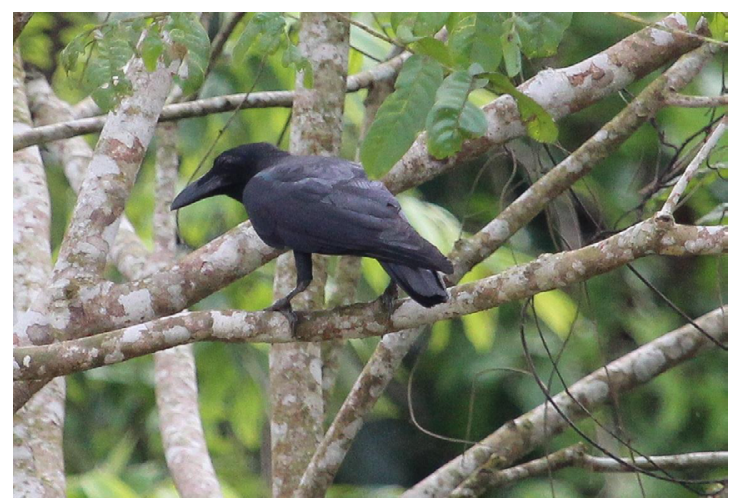

Gambar 8. Corvus enca

Deskripsi:

Sebagian besar di pesisir dan dataran rendah, sekitar pemukiman penduduk dan lahan budidaya yang pohonnya sedikit, termasuk kebun kelapa. Berukuran 34-45 $\mathrm{cm}$. Iris gelap. Hidup berpasangan dalam kelompok kecil, umumnya pemalu dan suka bertengger di ranting pohon yang besar dan tinggi. Sarang berukuran besar dan tidak rapi pada pucuk-pucuk pohon tinggi. Telur berwarna biru, berbintik hitam jumlah 3-4 butir.

\section{Turacoena manadensis}

Nama Lokal: Merpati Hitam Sulawesi Nama Internasional: Sulawesi Black Pigeon Kriteria Kepunahan: beresiko Rendah

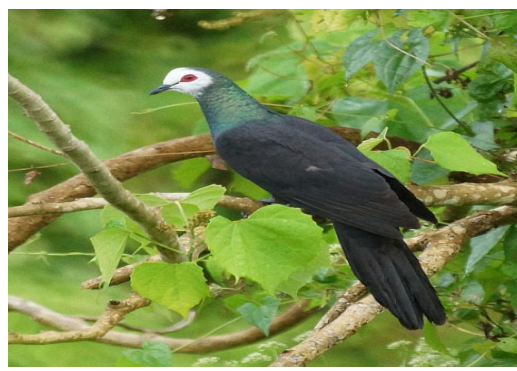

Gambar 9. Turacoena manadensis 
Deskripsi:

Cukup umum, menghuni lahan budidaya yang pohonnya jarang dan semak. Berukuran $40 \mathrm{~cm}$. Ekor lebar, agak panjang, muka putih, bagian lainnya sabak tua dengan warna hijau atau lembayung berkilap. Kulit sekeliling mata merah. Pada anak lebih kusam, muka tertutup warna abu-abu.

\section{Phaenicophaeus calyorhynchus}

Nama Lokal: Kadalan Sulawesi

Nama Internasional: yellow billed Malkoha Kriteria Kepunahan: Beresiko Rendah

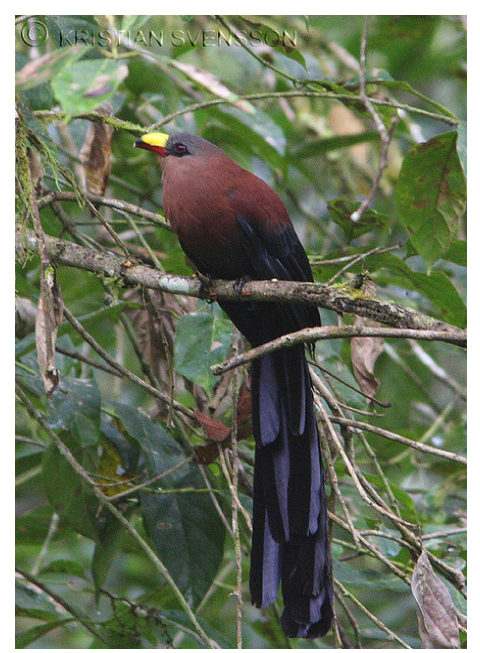

Gambar 10. Phaenicophaeus calyorhynchus

Deskripsi:

Cukup umum, menghuni semak dan lahan budidaya yang pohonnya jarang. Berukuran 51-53 cm. Paruh tebal. Sebagian kuning terang, bagian depan kadru. Ekor hitam panjang. Burung ini melompat dengan agak berat di lapisan tajuk pohon dan perdu.

\section{Dicrurus hottentottus}

Nama Lokal: Srigunting Jambul Rambut Nama Internasional: Hair Crested Drongo Kriteria Kepunahan: Beresiko Rendah

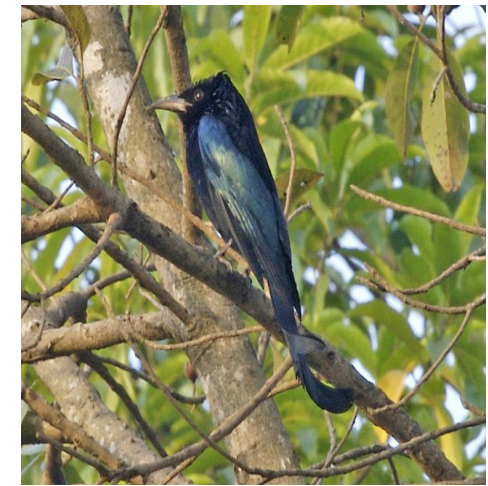

Gambar 11. Dicrurus bottentottus

Deskripsi:

Berukuran 29-32 cm. Iris berwarna putih. Biasanya umum, menghuni kawasan yang pohonnya jarang dan semak. Tubuh warna hitam mengkilap. Bulu berbintik mengkilap terang. Ekor panjang terbelah tumpul, ujung bulu terluar tertekuk membentuk huruf U. Makanan berupa kumbang, rayap, lebah dan serangga besar. Sarang berbentuk cawan yang dijalin pada dahan manggarpu dekat tanah. Telur berwarna kemerahjambuan berbintik merah yang berjumlah 3-4 butir.

\section{Todiramphus chloris}

Nama Lokal: Cekakak Sungai

Nama Internasional: Collared Kingfisher

Kriteria Kepunahan: Beresiko Rendah

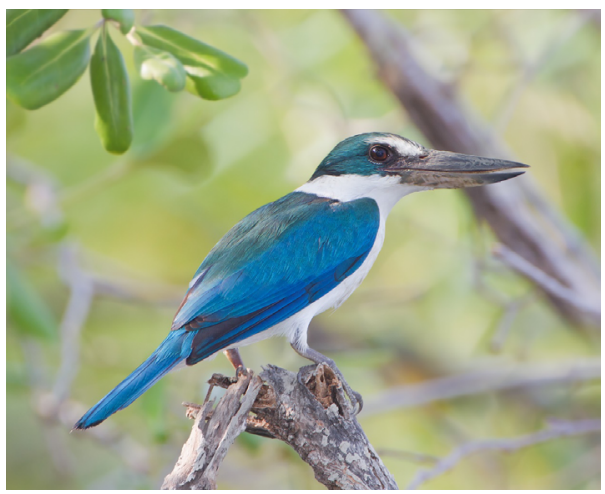

Gambar 12. Todiramphus chloris 
Deskripsi:

Berukuran 24-56 cm. Mahkota dan bagian atas biru hingga hijau biru. Kerah leher belakang dan bagian bawah putih, paruhnya kokoh. Tengkuk sering kelihatan pucat keputih-putihan. Dijumpai secara umum, menghuni lahan budidaya yang pohonnya sedikit, pekarangan, dan perkebunan kelapa. Memiliki kebiasaan bertengger di bebatuan, pohon-pohon, dan kabel listrik. Makanan berupa kadal, serangga besar, katak, ulat dan cacing. Memiliki suara sangat ribut. Sarang berupa galian, di bawah pohon atau tepi sungai. Telur berjumlah 2 sampai 3 butir berwarna putih.

\section{Hirundo tabitica}

Nama Lokal: Layang-Layang Batu Nama Internasional: Pacific Swallow Kriteria Kepunahan: Beresiko Rendah

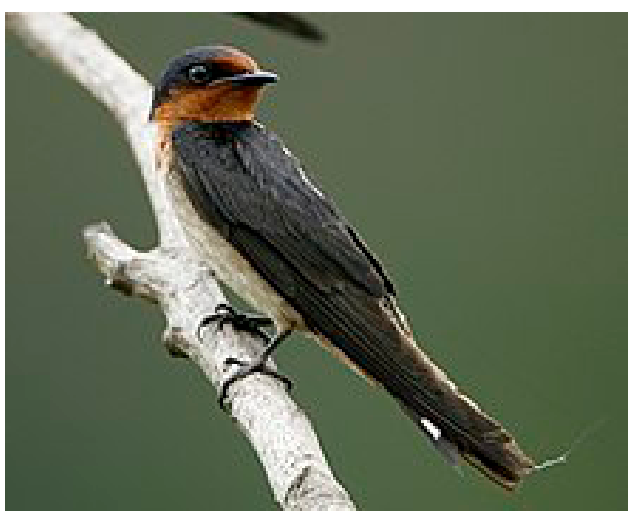

Gambar 13. Hirundo tabitica

Deskripsi:

Jenis pemakan serangga yang makan sambil terbang dan bertengger dalam kelompokkelompok pada kawat telepon atau tiang listrik. Terbang menyambar dengan sayapsayap yang agak melengkung dan ekor yang sedikit bercabang. Layang-layang batu merupakan jenis penetap yang umum di desa-desa, mencari makan di pedesaan yang terbuka, misalnya sawah, padang rumput, lahan budidaya, sungai-sungai, dan rawa-rawa. Sering ditemukan di sekitar pemukiman penduduk khususnya dekat air.Membangun sarang lumpur di bagian atap-atap rumah. Bagian atas biru gelap, muka dan tenggorokan merah karat, dada tidak terlalu jelas. Bagian bawah putih keabu-abuan, tanpa bulu ekor tengah.

\section{Aethopyga siparaja}

Nama Lokal: Burung Madu Sepah Raja Nama Internasional: Crimson Sunbird Kriteria Kepunahan: Beresiko Rendah

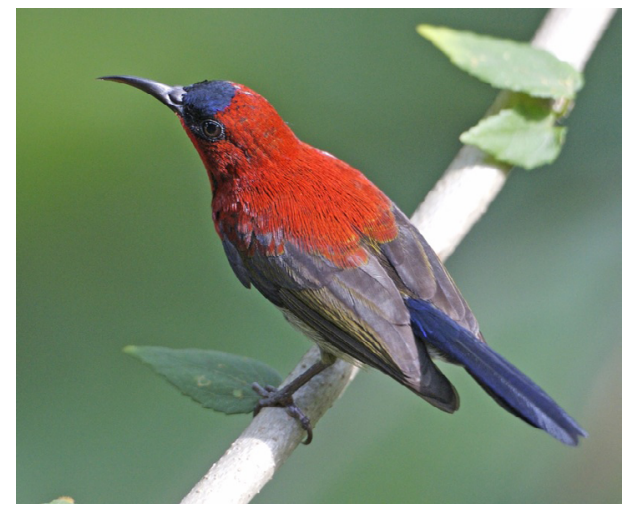

Gambar 14. Aethopyga siparaja

Deskripsi:

Burung madu merupakan suku yang terdiri dari burung-burung kecil pemakan nektar yang sangat berbeda dengan burung cabai. Paruh tipis dan melengkung serta warnawarna metalik pada jantan. Burung madu sepah raja memiliki ukuran tubuh sedang yaitu sekitar $13 \mathrm{~cm}$. Pada jantan memiliki warna merah terang, dahi dan ekor pendek, perut lebih abu-abu gelap. Betina memiliki warna yang berbeda yaitu hijau tua zaitun tanpa sapuan merah pada sayap atau ekor. Makanan berupa nektar. Telur berwarna merah jambu dan berbintik biasanya berjumlah dua butir.

Burung ini merupakan burung herbivora. Tersedianya pakan merupakan hal penting bagi burung, terutama burung herbivora. Burung herbivora adalah jenis burung yang pakannya terutama berasal dari tumbuhan, seperti biji-bijian, kacang-kacangan (granivora), daun-daunan, rumputrumputan, tunas (folivora), buah buahan (frugivora) (Plein et al., 2013), nektar dan pollen (nektivora), dan cairan tumbuhan (Zobrist, 2014). 


\section{Nectarinia jugularis}

Nama Lokal: Burung Madu Sriganti

Nama Internasional: Olive Backed Sunbird

Kriteria Kepunahan: Beresiko Rendah

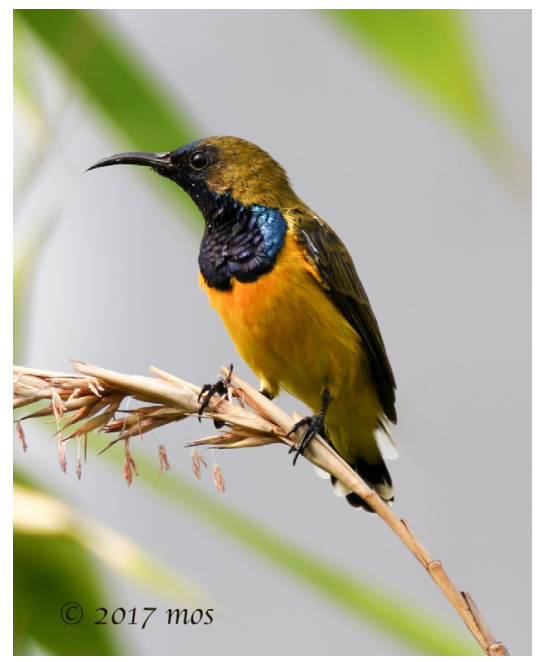

Gambar 15. Nectarinia jugularis

Deskripsi:

Burung madu sriganti dijumpai di semak dan pekarangan. Berukuran $11 \mathrm{~cm}$. Jantan memiliki penampilan bagian atas zaitun, bercak tenggorokan dan bercak dada biru lembayung metalik tua. Pada betina bagian atas zaitun, bagian bawah kuning, alis kuning dan sebagian besar bulu ekor luar putih. Sering ribut dalam kelompok kecil, berpindah-pindah dari satu pohon atau semak ke yang lain. Makanan berupa benalu, serangga kecil, nektar. Sarang berbentuk seperti kantung terbuat dari rumput yang terjalin dengan kapas alangalang pada dahan yang rendah.

\section{Passer montanus}

Nama Lokal: Burung Gereja Erasia

Nama Internasional: Euraasian Tree Sparrow

Kriteria Kepunahan: Beresiko Rendah

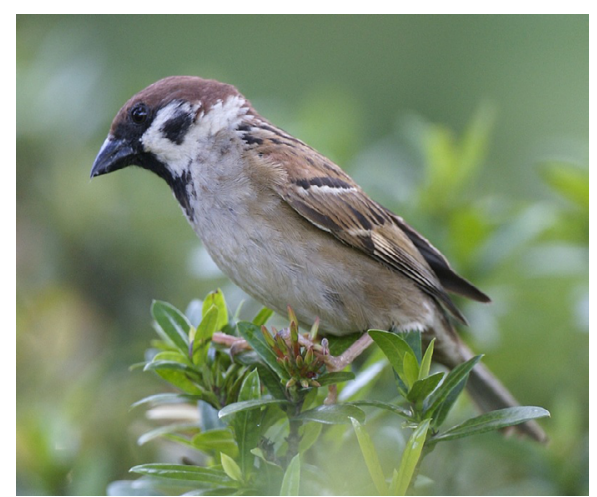

Gambar 15. Passer montanus

Deskripsi:

Burung gereja adalah sejenis burung pipit kecil. Diantara semua jenis burung liar, burung gereja adalah yang paling jinak. Biji-bijian dan serangga kecil adalah makanannya. Dapat dijumpai secara luas dan melimpah di pedesaan. Berukuran 14-15 cm, berekor pendek, tudung kadru terdapat bintik hitam pada pipi, pada remaja bintik ini tidak ada serta memiliki paruh yang kuat.

\section{Gallus gallus}

Nama Lokal: Ayam Hutan Merah Nama Internasional: Red Junglefowl Kriteria Kepunahan: Beresiko Rendah

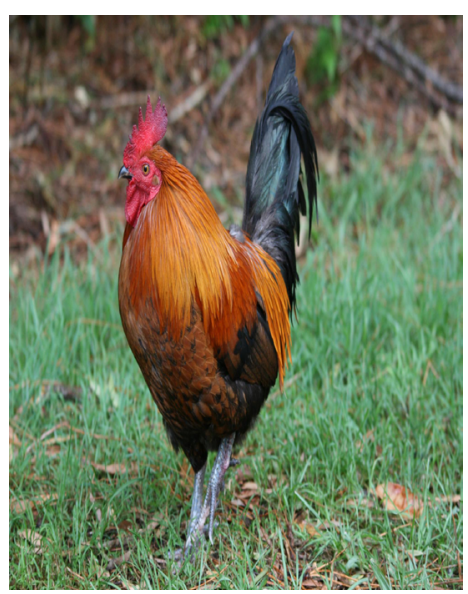

Gambar 16. Gallus gallus 
Deskripsi:

Menghuni semak dan pekarangan. Jantan memiliki ukuran yang lebih besar dibandingkan betina yaitu $70 \mathrm{~cm}$, sedangkan betina hanya $43 \mathrm{~cm}$. Jantan memiliki bulu-bulu leher, tengkuk dan mantel panjang meruncing berwarna kuning coklat keemasan dengan kulit muka merah, di kepalanya terdapat jengger bergerigi dan gelambir berwarna merah. Kaki berwarna kelabu dengan sebuah taji. Ayam betina menetaskan antara lima sampai enam butir telur berwarna coklat muda atau coklat kemerahan.

\section{Loriculus stigmatus}

Nama Lokal: Serindit Sulawesi

Nama Internasional: Sulawesi Hanging Parrot

Kriteria Kepunahan: Beresiko Rendah

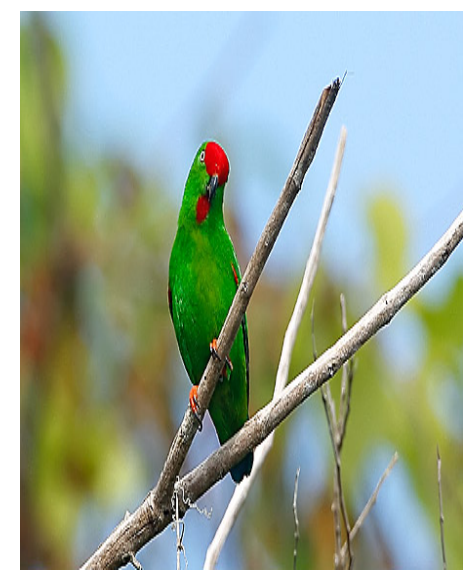

Gambar 18. Loriculus stigmatus

\section{Deskripsi:}

Memiliki ukuran 15-15,5 cm. Umumnya hijau, bercak di tenggorokan merah, tunggir merah tua. Tanda merah pada tepi sayap depan. Paruh berwarna hitam. Pada jantan: dahi dan mahkota merah, iris kuning pucat. Betina: dahi dan mahkota hijau, iris coklat. Dijumpai umum, menghuni lahan budidaya yang pohonnya jarang, semak, dan perkebunan kelapa. Jenis serindit ini umum pada pohon-pohon yang sedang berbunga.

\section{Pycnonotus aurigaster}

Nama Lokal: Cucak Kutilang

Nama Internasional: Sooty Heade Bulbul

Kriteria Kepunahan: Beresiko Rendah

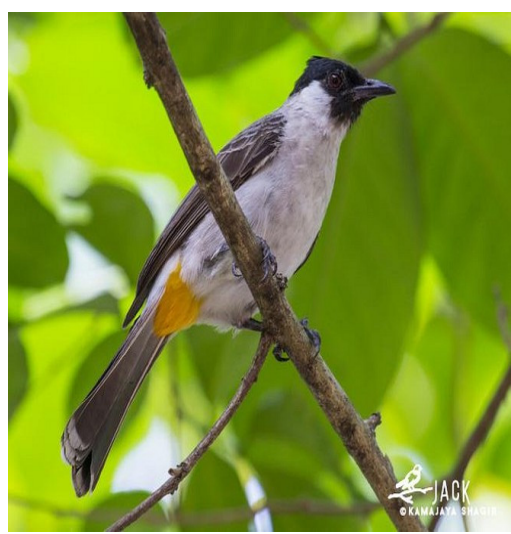

Gambar 19. Pycnonotus aurigaster

Deskripsi:

Memiliki ukuran $20 \mathrm{~cm}$. Muka dan makhota hitam, bercak tunggir keputihputihan, ekor gelap dan ujungnya keputihputihan, tungging kuning jingga. Terdapat di lahan-lahan budidaya yang pohonnya sedikit, semak dan rawa-rawa. Memiliki kebiasaan berjemur dan mandi embun setiap pagi. Sarang berbentuk cawan dari anyaman daun rumput atau ranting yang halus. Jumlah telur dua sampai tiga, berwarna kemerah jambuan dengan bintik ungu dan abu-abu pucat.

\section{Gallirallus torquatus}

Nama Lokal: Burung Weris/Burung Mandar Padi Zebra/ Burung Kruwo Nama Internasional: Buff Handed Rail Kriteria Kepunahan: Beresiko Rendah

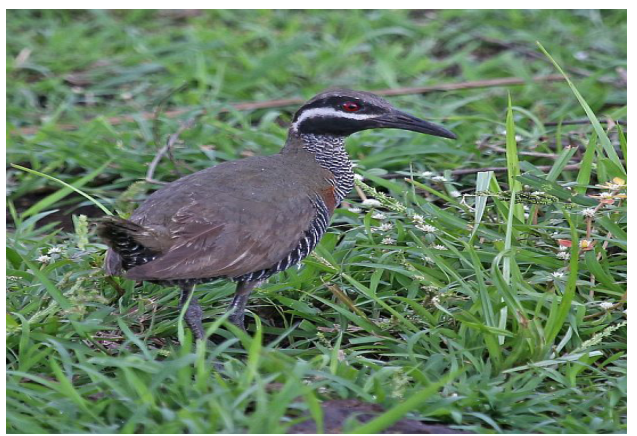

Gambar 20. Gallirallus torquatus

Slamet Mardiyanto Rahayu-95 
Deskripsi:

Biasanya umum. Menghuni padang rumput, semak, dan lahan budidaya. Berukuran 28-34 cm. Muka, tenggorokan dan bagian bawah hitam dengan sebuah setrip putih panjang pada pipi, dada dan bagian bawah berpalang putih. Sayap membundar pendek dan ekor pendek, serta cenderung untuk terbang lemah dengan kakinya yang menjuntai.

\section{Ninox punctulata}

Nama Lokal: Manguni/ Punggok Tutul Nama Internasional: Spekled Hawk Owl Kriteria Kepunahan: Beresiko Rendah

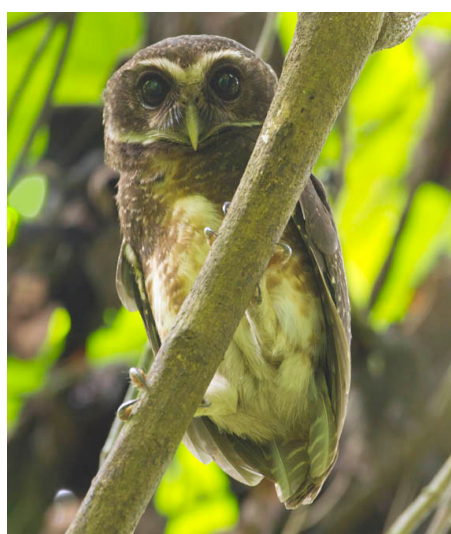

Gambar 21. Ninox punctulata

\section{Deskripsi:}

Tidak memiliki piringan muka datar seperti yang dimiliki oleh kebanyakan burung hantu, sehingga tampak seperti burung elang yang agak gemuk dan pendek. Berukuran $27 \mathrm{~cm}$. Topeng kehitaman, alis dan setrip-dahi dan keputih-putihan, mata coklat, tenggorokan keputih-putihan, bagian bawah coklat kemerahan, berpalang dan berbintik putih.

\section{Otus manadensis}

Nama Lokal: Celepuk Sulawesi

Nama Internasional: Sulawesi Scops Owl

Kriteria Kepunahan: Beresiko Rendah

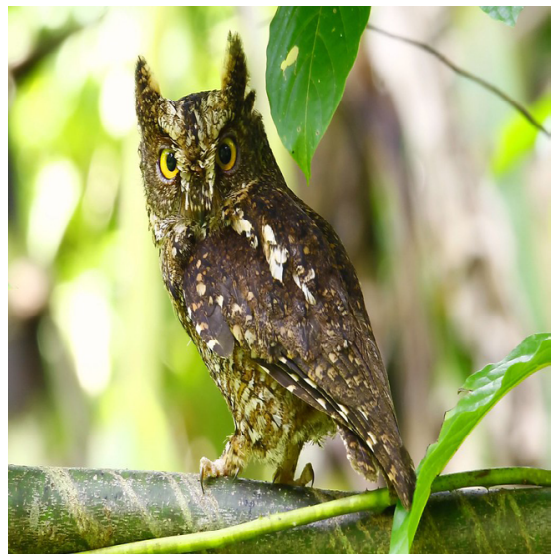

Gambar 22. Otus manadensis

Deskripsi:

Umum, menghuni lahan budidaya yang pohonnya sedikit dan perdu. Memiliki ukuran $21 \mathrm{~cm}$. Merupakan satu-satunya celepuk yang bertelinga dengan dada bercoret-coret hitam (Arini dkk., 2011).

\section{Phylloscopus sarasinorum}

Nama Lokal: Cikrak Sulawesi

Nama Internasional: Sulawesi Leaf Warbler Kriteria Kepunahan: Beresiko Rendah

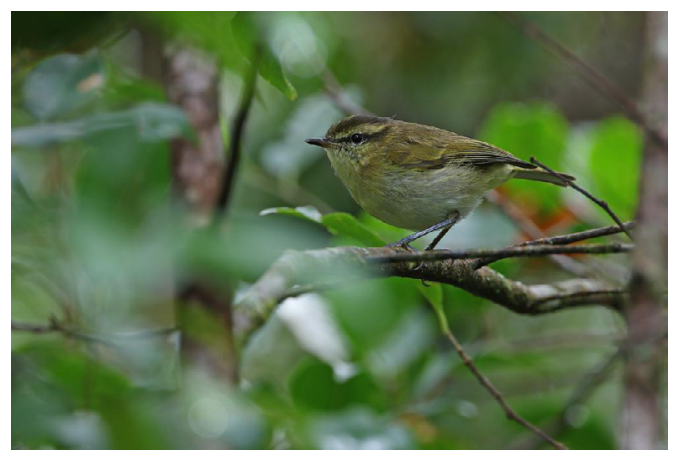

Gambar 23. Phylloscopus sarasinorum

Deskripsi:

Salah satu jenis burung bawah tajuk yang umum dijumpai di tepi hutan. Berukuran $11 \mathrm{~cm}$. Coret alis panjang dan pucat yang merupakan ciri khas, lainnya tidak dapat dibedakan, bagian atas berwarna zaitun dan bagian bawah pucat, sisi-sisi lebih gelap, tungkai abu-abu sabak. 


\section{Bubulbus ibis}

Nama Lokal: Kuntul Kerbau

Nama Internasional: Cattle Egret

Kriteria Kepunahan: Beresiko rendah

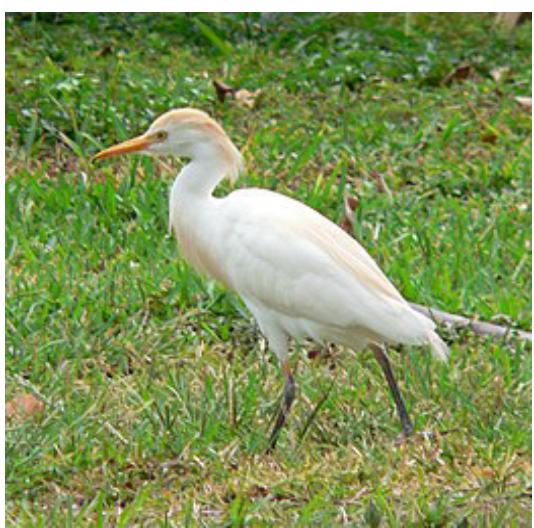

Gambar 24. Bubulbus ibis

Deskripsi:

Berukuran 48-53 cm. Paruh pendek, leher gemuk, tenggorokan kokoh, paruh kuning, tungkai dan kaki kuning kehijauan. Jika terbang biasanya akan terlihat seperti huruf "s" dan jenis terkecil dari marga kuntul.
Ada sepanjang tahun, sering mengunjungi kawasan terbuka khususnya padang rumput, sawah-sawah yang tergenang sebagian, rawa-rawa dan kadang gosong lumpur. Makanan berupa ikan, katak, dan hewan invertebrata.

\section{Simpulan}

Ditemukan 23 jenis avifauna di Desa Makmur Jaya, Kecamatan Tikke Raya, Kabupaten Pasangkayu, Provinsi Sulawesi Barat, yaitu: Alcedo atthis, Aythya australis, Rhyticeros cassidix, Chalcophaps stephani, Streptopelia chinensis, Macropygia amboinensis albicapilla, Corvus enca, Turacoena manadensis, Phaenicophaeus calyorhynchus, Dicrurus hottentottus, Todiramphus chloris, Hirundo tahitica, Aethopyga siparaja, Nectarinia jugularis, Passermontanus, Gallus gallus, Loriculusstigmatus, Pycnonotus aurigaster, Gallirallus torquatus, Ninox punctulata, Phylloscopus sarasinorum, dan Bubulbus ibis.

\section{Daftar Pustaka}

Agyei-Ohemeng, J., Danquah, E., \& Adu Yeboah, B. (2017). Diversity and Abundance of Bird Species in Mole National Park, Damongo, Ghana. Journal of Natural Sciences Research, 7(12), 20-33-33.

Arini, D. I. D., Shabri, S., Kafiar, Y., Tabba, S., \& Kamma, H. (2011). Keanekaragaman Avifauna Beberapa Kawasan Konservasi Propinsi Sulawesi Utara dan Gorontalo. Manado: Balai Penelitian Kehutanan Manado, Badan penelitian dan Pengembangan Kehutanan, Kementerian Kehutanan.

Atmoko. (2011). Burung Sebagai Indikator Keanekaragaman Hayati. Buletin Walet 2 (2), 3 - 5.

Balvanera, P., Pfisterer, A. B., Buchmann, N., He, J.-S., Nakashizuka, T., Raffaelli, D., \& Schmid, B. (2006). Quantifying the evidence for biodiversity effects on ecosystem functioning and services. Ecology Letters, 9(10), 1146-1156. https://doi.org/10.1111/j.1461-0248.2006.00963.x

Chace, J. F., \& Walsh, J. J. (2006). Urban effects on native avifauna: a review. Landscape and Urban Planning, 74(1), 46-69. https://doi.org/10.1016/J.LANDURBPLAN.2004.08.007

Chemini, C., \& Rizzoli, A. (2014). Land use change and biodiversity conservation in the Alps. Journal of Mountain Ecology, 7(0). Retrieved from http://www.mountainecology.org/index. $\mathrm{php} / \mathrm{me} /$ article/view/133

Indrawan, M., Primack, R. B., \& Supiatna, J. (2007). Biologi Konservasi. Jakarta: Yayasan Obor Indonesia. 
Ladin, Z. S., Higgins, C. D., Schmit, J. P., Sanders, G., Johnson, M. J., Weed, A. S., ... Shriver, W. G. (2016). Using regional bird community dynamics to evaluate ecological integrity within national parks. Ecosphere, 7(9), e01464. https://doi.org/10.1002/ecs2.1464

Martin, T. E., \& Blackburn, G. A. (2010). Impacts of Tropical Forest Disturbance Upon Avifauna on a Small Island with High Endemism: Implications for Conservation. Conservation and Society, 8(2), 127. https://doi.org/10.4103/0972-4923.68914

Misana, S. B., Majule, A., \& Lyaruu, H. (2003). Linkages between changes in land use, biodiversity and land degradation on the slopes of Mount Kilimanjaro, Tanzania. LUCID Working Papers, $38,1-30$.

N.S. Sodhi, C.H. Şekercioğlu, J. Barlow, \& S.K. Robinson. (2011). Conservation of tropical birds. Retrieved from https://books.google.co.id/books?hl=en\&lr=\&id=hs2nR8Q-Qv4C\&oi= fnd\&pg=PA1993\&dq=Conservation + of + Tropical+Birds\&ots=P581QHfDIL\&sig=kGS IWqXfFeVEf3EKMzY_6LTJoNI\&redir_esc=y\#v=onepage\&q=Conservation of Tropical Birds\&f=false

Nic Lughadha, E., Baillie, J., Barthlott, W., Brummitt, N. ., Cheek, M. ., Farjon, A., ... Crane, P. . (2005). Measuring the fate of plant diversity: towards a foundation for future monitoring and opportunities for urgent action. Philosophical Transactions of the Royal Society B: Biological Sciences, 360(1454), 359-372. https://doi.org/10.1098/rstb.2004.1596

Plein, M., Längsfeld, L., Neuschulz, E. L., Schultheiß, C., Ingmann, L., Töpfer, T., ... Schleuning, M. (2013). Constant properties of plant-frugivore networks despite fluctuations in fruit and bird communities in space and time. Ecology, 94(6), 1296-1306. https://doi.org/10.1890/121213.1

Ramirez, J. (2010). The Effect of Land Use Intensity on Biodiversity of Bird and Plant in the Central Mexican Mattoral of Hidalgo Mexico (Thesis). Mexico: Eastern New Mexico University.

Rusmendro, H., Ruskomalasari, Khadafi, A., Prayoga, H. B., \& L. Apriyanti. (2009). Keberadaan Jenis Burung pada Lima Stasiun Pengamatan di Sepanjang Daerah Aliran Sungai (DAS) Ciliwung Depok Jakarta. Vis Vitalis 2, 50-64.

Şekercioğlu, Ç. H. (2012). Promoting community-based bird monitoring in the tropics: Conservation, research, environmental education, capacity-building, and local incomes. Biological Conservation, 151(1), 69-73. https://doi.org/10.1016/J.BIOCON.2011.10.024

Sekercioglu, C. H., Ehrlich, P. R., Daily, G. C., Aygen, D., Goehring, D., \& Sandi, R. F. (2004). Ecosystem consequences of bird declines. Proceedings of the National Academy of Sciences of the United States of America, 101(52), 18042-18047. https://doi.org/https://doi.org/10.1073/ pnas. 0408049101

Tallei, T. E., Saroyo, \& Tallei, V. R. (2018). Wild birds diversity in Mount Tumpa Forest Park, North Sulawesi, Indonesia. Bioscience Research, 15(1), 443-452.

Tobias, J., Vargas, F. H., \& Şekercioğlu, C. H. (2013). Bird Conservation in Tropical Ecosystems: Challenges and Opportunities. John Wiley \& Sons, Ltd.

Zebisch, M., Wechsung, F., \& Kenneweg, H. (2004). Landscape response functions for biodiversityassessing the impact of land-use changes at the county level. Landscape and Urban Planning, 67(1-4), 157-172. https://doi.org/10.1016/S0169-2046(03)00036-7

Zobrist, K. W. (2014). Recognizing sapsucker damage to your trees. Washington State University extension fact sheet. Seattle, USA: Washington State University. 